\title{
Synbiotic-like effect of linoleic acid overproducing Lactobacillus casei with berry phenolic extracts against pathogenesis of enterohemorrhagic Escherichia coli
}

\author{
Zajeba Tabashsum ${ }^{1 \dagger}$, Mengfei Peng ${ }^{2 \dagger}$, Cassendra Bernhardt ${ }^{2}$, Puja Patel ${ }^{1}$, Michael Carrion ${ }^{1}$ \\ and Debabrata Biswas ${ }^{1,2,3 *}$ (1)
}

\begin{abstract}
Background: Majority of enteric infections are foodborne and antimicrobials including antibiotics have been used for their control and treatment. However, probiotics or prebiotics or their combination offer a potential alternative intervention strategy for improving the host health and preventing foodborne pathogen colonization/infections in reservoir. Further, bioengineered probiotics expressing bioactive products to achieve specific function is highly desirable. Recently, we over-expressed mcra (myosin cross-reactive antigen) gene in Lactobacillus casei (LC) and developed a bioengineered probiotics LC + CLA which produce higher amounts of metabolites including conjugated linoleic acid (CLA). Furthermore, we also reported that prebiotic like components such as berry pomace (byproduct) phenolic extracts (BPEs) can enhance the growth of probiotics and improved the beneficial effects of probiotics. In this study, we evaluated the antimicrobial effect of modified LC + CLA in combination of BPEs on growth, survival and pathogenesis of enterohemorrhagic Escherichia coli (EHEC).
\end{abstract}

Results: In mixed culture condition, the growth of EHEC was significantly reduced in the presence LC $+\mathrm{CLA}$ and/or BPEs. Cell-free cultural supernatant (CFCS) collected from Lc or LC + CLA strain also inhibited the growth and survival of EHEC and the inhibitory effects of CFCSs against EHEC were enhanced in the presence of BPEs in concentration dependent manner. Interaction between EHEC and intestinal epithelial INT-407 cells were also altered significantly in the presence of either LC or LC +CLA strain or their CFCSs with or without BPEs. The expression of multiple virulence genes and physicochemical properties of EHEC were also altered when the bacterial cells were pretreated with CFCSs and/or BPEs.

Conclusions: These results showed that diet containing bioactive LC +CLA and natural prebiotic like component such as BPEs might be an effective way to prevent foodborne infections with EHEC.

Keywords: EHEC, Prebiotic, Probiotic, Synbiotic, Prevention

\footnotetext{
*Correspondence: dbiswas@umd.edu

${ }^{\dagger}$ Zajeba Tabashsum and Mengfei Peng contributed equally to this work

2 Department of Animal and Avian Sciences, University of Maryland, 8127

Regents Drive, College Park, MD, USA

Full list of author information is available at the end of the article
} 


\section{Background}

Majority of enteric infections are foodborne and, in most case, bacteria are the major pathogenic agents followed by viruses, and then parasites. Among the enteric bacterial pathogens, Enterohemorrhagic Escherichia coli (EHEC) is one of the pre-dominants enteric bacterial pathogen in the USA and other developed countries. EHEC is frequently isolated from beef and other food products such as produce as well as recorded as a top ranked foodborne bacterial pathogenic agents in respect to mortality and morbidity $[1,2]$. Enteric infection with EHEC also can lead to kidney failure due to the severe cytotoxic effect of EHEC known as Hemolytic Uremic Syndrome (HUS) [1]. This effect could be intensified due to the antibiotic therapy [2]. In addition, with high incidence of antibiotic resistance in EHEC [3], the development of novel bio-therapeutics against this specific enteric bacterial pathogen, is more crucial than ever.

Probiotic, as predominate part of gut microbial ecosystem, plays critical roles in maintaining the balance of human GI ecosystems and prevent the enteric infections by limiting colonization of enteric pathogen [4-6]. In addition, with host health promotion, probiotics showed several defensive or beneficial activities against pathogens including competitive exclusion, inhibition of bacterial protein synthesis, limiting quorum sensing, secretion of proteins, and their motility/mobility [4-8]. However, all these beneficial roles of probiotics against enteric bacterial pathogens generally depend on the ratio of probiotic within the gut ecosystems and the total amount of bioactive metabolites specifically short chain fatty acids and other acids produced by them.

On the other hand, the use of dietary plant phenolic extracts is becoming an attractive alternative therapy [9-11]. Fruit byproducts, especially blackberry (Rubus fruticosus) and blueberry (Vaccinium corymbosum) byproducts commonly known as pomace, contain bioactive phenolics including flavan, flavanone, flavones, glucuronides, glucosides, quinolones, catechol, coumarin, phenols, luteolines, tannins, quercetin, chlorogenic acid, ellagic acid, gallic acid, xanthoxic acid [12]. Recent reports have shown that berry pomace phenolic extracts (BPEs) are antimicrobial against a wide variety of enteric bacterial pathogens [13-16] and in the presence of BPEs, growth of beneficial bacterial/probiotic is enhanced with increased production of the bioactive metabolites [17-20].

Combination of probiotic and prebiotic, known as synbiotics, have emerged as a promising alternative treatment approach and can improve and maintain host health; beneficial effects depend largely upon the total quantity of probiotics and the amount and type of functional byproducts (proteins and peptides) they produce.
In a recent study, we found that in the presence of the prebiotic-like component peanut flour, Lactobacillus casei (Lc) produced 100 times more linoleic acid (LA) than under normal condition and was able to outcompete several enteric bacterial pathogens [13, 21, 22]. On the basis of such observation, we have overexpressed the linoleate isomerase (myosin cross-reactive antigen, mcra) gene in a natural, sustainable Lc strain in order to enhance the production of conjugated linoleic acids (CLA) $[23,24]$ and verify the ability of this genetically engineered strain (Lc + CLA) to inhibit growth and infection of host cells by EHEC in vitro.

In this study, we assess the effect of genetically modified L. case $i$ with increased production ability of CLA, known as Lc + CLA in combination with various concentration of BPEs against the growth and survival ability EHEC and its interaction with cultured human intestinal epithelial (INT-407) cells. Further, we also compare expression levels of EHEC virulence mediatory genes, and physicochemical properties in the presence or absence of the probiotic strains and/or bioactive phenolic extracts.

\section{Results}

Growth inhibition of EHEC in presence or absence of probiotic strains and/or pomace phenolic extracts

To determine the effect of prebiotic like component BPEs, probiotic strain Lc or Lc + CLA or the metabolites produced by Lc or Lc + CLA in CFCSs on the growth inhibition of EHEC, we co-cultured EHEC with Lc or Lc + CLA or their CFCSs with different concentrations of BPEs $[0.1 \mathrm{mg} / \mathrm{ml}$ gallic acid equivalent (GAE) or $0.5 \mathrm{mg} /$ $\mathrm{ml} \mathrm{GAE}$ or $1.0 \mathrm{mg} / \mathrm{ml} \mathrm{GAE}$. In the presence of BPEs either of $0.1 \mathrm{mg} / \mathrm{ml}$ GAE or $0.5 \mathrm{mg} / \mathrm{ml} \mathrm{GAE}$, the growth of EHEC was not significantly reduced compared to the control but when the concentration of BPE was raised to $1.0 \mathrm{mg} / \mathrm{ml} \mathrm{GAE}$, the growth of EHEC was reduced significantly within $24 \mathrm{~h}$ (Fig. $1 \mathrm{~A}-\mathrm{C}$ ). Further, either probiotic strain, Lc or Lc + CLA in combination with $0.1 \mathrm{mg} /$ $\mathrm{ml} \mathrm{GAE}$ or $0.5 \mathrm{mg} / \mathrm{ml} \mathrm{GAE}$ or $1.0 \mathrm{mg} / \mathrm{ml} \mathrm{GAE}$ of BPEs intensified the reduction of the growth of EHEC in a time dependent manner but the inhibitory effect of Lc+CLA in presence of $1.0 \mathrm{mg} / \mathrm{ml} \mathrm{GAE}$ was observed at maximum level [ $>8.0$ logs colony forming unit (CFU)/ml reduction] than the other treatments (Fig. 1C). CFCS collected from of Lc (CFCS-Lc) or Lc + CLA (CFCS-Lc + CLA) in the presence of BPEs of different concentrations also showed inhibitory effects on the growth of EHEC (Fig. 1A-C). After $24 \mathrm{~h}$, the reduction in the growth of EHEC was observed ranging from $<1.0 \mathrm{log}$ CFU $/ \mathrm{ml}$ (CFCS-Lc in presence of $0.1 \mathrm{mg} / \mathrm{ml} \mathrm{GAE}$ of BPE) to $>3.0 \mathrm{logs} \mathrm{CFU} /$ $\mathrm{ml}$ (CFCS-Lc + CLA in presence of $1.0 \mathrm{mg} / \mathrm{ml} \mathrm{GAE}$ of BPE). After $48 \mathrm{~h}$ of incubation, the growth of EHEC was reduced more than $3.0 \operatorname{logs} \mathrm{CFU} / \mathrm{ml}$ by CFCS-Lc 

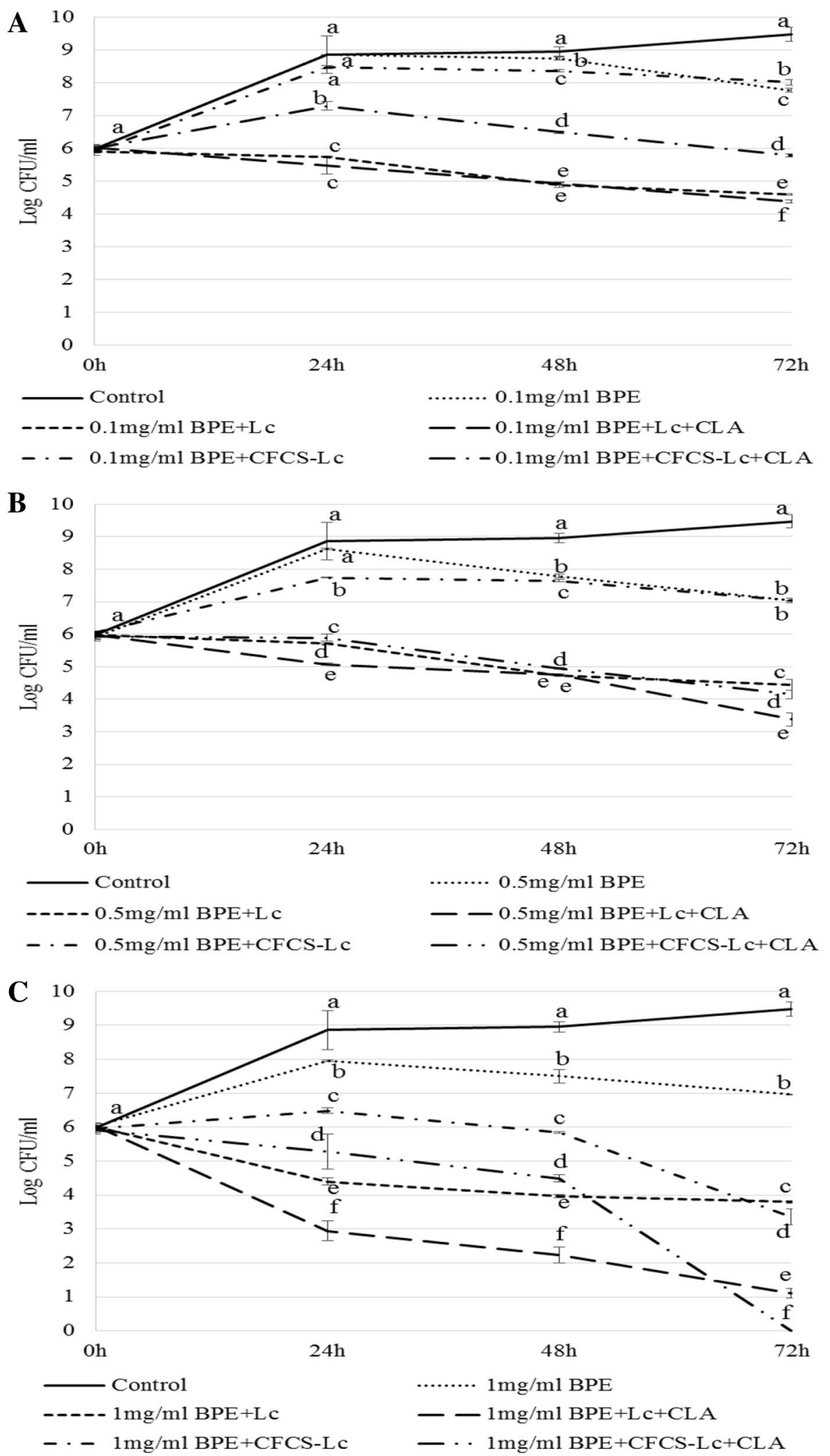

Fig. 1 Growth pattern of EHEC (A-C) at various time $(24,48$, and $72 \mathrm{~h})$ points with or without treatments. Error bars indicate standard deviation from 6 parallel trails. Different letters $(a-f)$ at each time point indicate the significant growth reduction when compared with single culture as a control and among the treatments at $p<0.05$ 
in presence of $1.0 \mathrm{mg} / \mathrm{ml} \mathrm{GAE}$ of BPEs and more than $4 \operatorname{logs} \mathrm{CFU} / \mathrm{ml}$ by CFCS-Lc + CLA in presence of BPEs of $1.0 \mathrm{mg} / \mathrm{ml} \mathrm{GAE}$ concentration compared to control group (no CFCS or BPEs added to the growth medium). After $72 \mathrm{~h}$ of incubation, the most effective growth reduction of EHEC was observed by CFCS-Lc + CLA in presence of $1.0 \mathrm{mg} / \mathrm{ml} \mathrm{GAE}$ of BPEs with no detectable growth (Fig. 1C).

\section{Alteration of EHEC adhesion ability in cultured mammalian cells}

The adhesion ability of EHEC to INT-407 cells in the presence of different concentrations $(0.1 \mathrm{mg} / \mathrm{ml} \mathrm{GAE}$ or $0.5 \mathrm{mg} / \mathrm{ml} \mathrm{GAE}$ or $1.0 \mathrm{mg} / \mathrm{ml} \mathrm{GAE}$ ) of BPEs, in combination with Lc or Lc + CLA itself or their metabolites containing CFCSs (CFCS-Lc and CFCS-Lc+CLA) was reduced significantly from $0.5 \mathrm{log} \mathrm{CFU} / \mathrm{ml}$ to $4.0 \operatorname{logs}$ $\mathrm{CFU} / \mathrm{ml}$ (Fig. 2A-C). BPEs $(0.1 \mathrm{mg} / \mathrm{ml} \mathrm{GAE}$ or $0.5 \mathrm{mg} / \mathrm{ml}$ GAE) without the probiotics or their CFCSs, numerically reduced the adhesion ability, though $1.0 \mathrm{mg} / \mathrm{ml}$ GAE reduced adhesion ability around $0.6 \log \mathrm{CFU} / \mathrm{ml}$, significantly (Fig. 2A-C) when compared to the control (only medium without any treatments).

\section{Alteration of EHEC physicochemical properties in presence of BPEs and/or CFCSs collected from Lc or LC + CLA}

We observed that pre-treatments of EHEC with all the treatments accept $0.1 \mathrm{mg} / \mathrm{ml}$ GAE of BPE, significantly increased the percentage of injured bacterial cells ranging from 36.33 to $58.97 \%$ when compared to control (without any treatments in growth media) (Table 1). The autoaggregation capacity of EHEC decreased significantly by CFCS-Lc in presence of $1.0 \mathrm{mg} / \mathrm{ml} \mathrm{GAE}$ of BPE or CFCS$\mathrm{Lc}+\mathrm{CLA}$ in presence of $0.5 \mathrm{mg} / \mathrm{ml} \mathrm{GAE}$ or $1.0 \mathrm{mg} /$ $\mathrm{ml}$ GAE of BPEs, and CFCS-Lc + CLA in presence of $1.0 \mathrm{mg} / \mathrm{ml}$ GAE of BPE was the most effective when compared to control group. The auto-aggregation capacity of EHEC was reduced numerically by 0.1 or 0.5 or $1.0 \mathrm{mg} /$ $\mathrm{ml} \mathrm{GAE}$ of BPE, CFCS-Lc in presence of $0.1 \mathrm{mg} / \mathrm{ml} \mathrm{GAE}$ or $0.5 \mathrm{mg} / \mathrm{ml} \mathrm{GAE}$ of BPE, CFCS-Lc + CLA in presence of $0.1 \mathrm{mg} / \mathrm{ml}$ of GAE but not significantly (Table 1). We also found that cell surface hydrophobicity of EHEC was reduced significantly with all the pre-treatments ranging from 4.65 to $1.45 \%$ accept $0.1 \mathrm{mg} / \mathrm{ml} \mathrm{GAE} \mathrm{of} \mathrm{BPE.} \mathrm{Also,}$ $\mathrm{BPE}$ of $0.1 \mathrm{mg} / \mathrm{ml} \mathrm{GAE}$ concentration reduced the cell surface hydrophobicity of EHEC to $13.1 \%$ when compared to control group but only numerically (Table 1).

\section{Disruption of biofilm formation of EHEC with BPEs and/ or CFCSs collected from Lc or Lc + CLA}

Biofilm formation is the process of attachment to a surface which can affect the growth rate and gene transcription ability of a bacteria and when EHEC was incubated in presence of BPEs $(0.1 \mathrm{mg} / \mathrm{ml} \mathrm{GAE}$ or $0.5 \mathrm{mg} / \mathrm{ml} \mathrm{GAE}$ or $1.0 \mathrm{mg} / \mathrm{ml} \mathrm{GAE}$ ) without CFCSs (collected from overnight culture of Lc or Lc + CLA) the biofilm formation ability was reduced significantly around $1.0 \log \mathrm{CFU} / \mathrm{ml}$. BPEs in combination with CFCS-Lc or CFCS-Lc + CLA also reduced the biofilm formation ability of EHEC when compared to the control group (growth media without treatment), significantly from $<1.0 \mathrm{log} \mathrm{CFU} / \mathrm{ml}$ to $>4.4$ logs CFU/ml and CFCS-Lc + CLA was more effective in the reduction of the biofilm formation in presence of same concentration of BPE in comparison with CFCS-Lc (Fig. 3A).

\section{Effect of CFCSs collected from Lc or Lc + CLA} with or without BPEs on EHEC virulence gene expression Expression of espA gene of EHEC, which is responsible for encoding secreted protein related to signal transduction leading to $\mathrm{A} / \mathrm{E}$ lesion formation, was significantly down-regulated at a range from 1.2- to 62.5-folds by either CFCS-Lc or CFCS-Lc + CLA collected from Lc or Lc + CLA in the presence of different concentrations of BPEs (Fig. $4 \mathrm{a}-\mathrm{c}$ ). The expression level of espB and espD genes which are also involved in signal transduction leading to $\mathrm{A} / \mathrm{E}$ lesion formation were down regulated significantly ranging from 1.1 - to 28 -folds in the treatment assay. The expression level of eaeA encoding intimin protein required for intimate attachment was also down regulated significantly more than 1.1 -folds to more than 3.9-folds in the assay. The expression level of locus of enterocyte effacement (LEE)-encoded regulator, ler was downregulated significantly $>1.3$ - to $>8.5$-folds by all the concentrations of BPEs with or without CFCS-Lc or CFCS-Lc + CLA. The expression level of tir responsible for translocated intimin receptor was also downregulated around onefold by different concentrations of BPEs with or without CFCS-Lc or CFCS-Lc + CLA (Fig. 4a-c).

\section{Discussions}

In this study, the combined effect of Lc + CLA, the probiotic strain with enhanced ability of conjugated linoleic acid (CLA) production, and bioactive phenolic compounds, BPEs extracted from blackberry and blueberry pomaces (byproducts), on the growth, survival and physicochemical properties of EHEC and in alteration of its interactions with human intestinal epithelial (INT-407) cells was investigated. BPE which showed its anti-oxidation and modulation ability of gut microbiome positively in our previous chicken trial [25], was tested in this study to amplify the beneficial effects of Lc or Lc + CLA.

We observed the synergistic effect of Lc or Lc+CLA and BPEs enhance the inhibiting ability of the growth of EHEC but the effect of BPE depends on concentration and duration of treatment period. These findings 
A 8

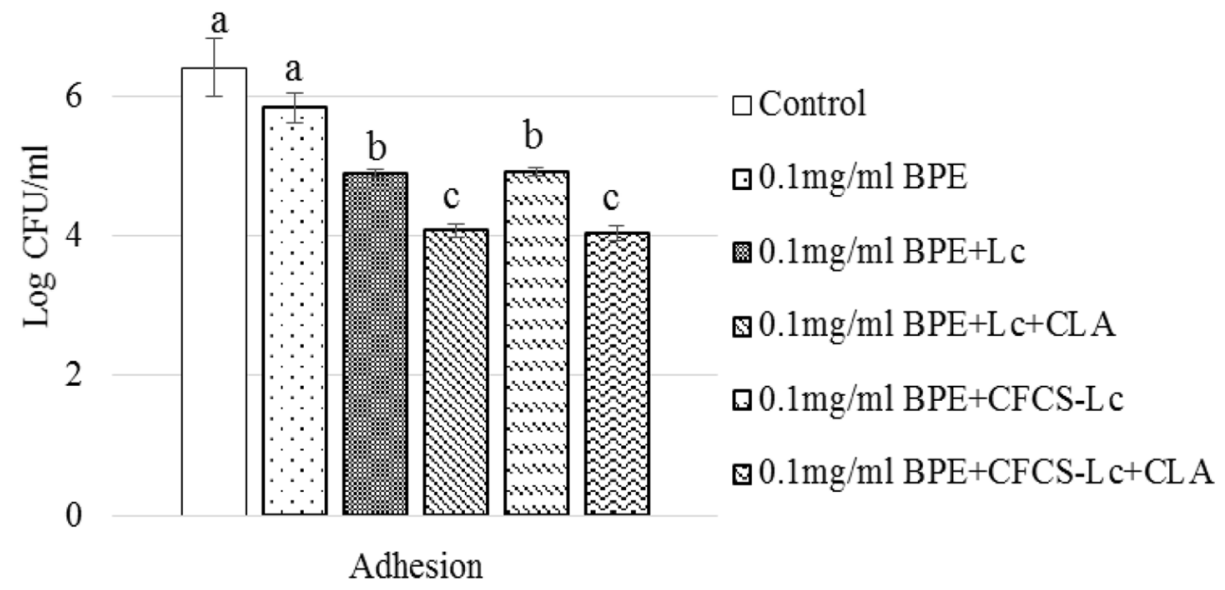

B 8

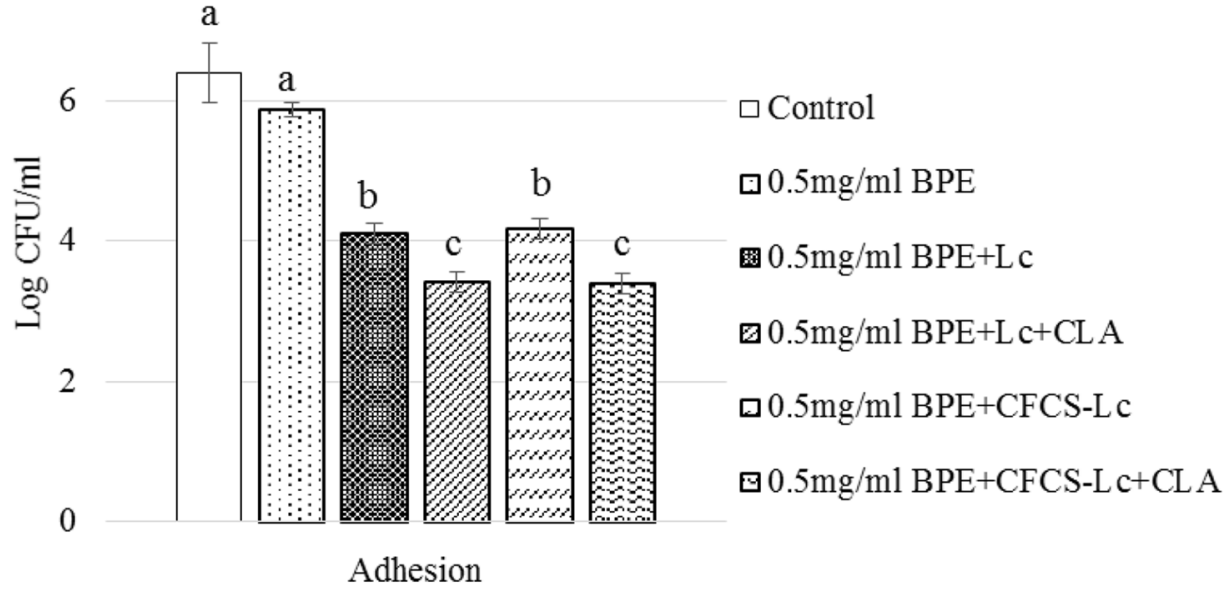

C 8

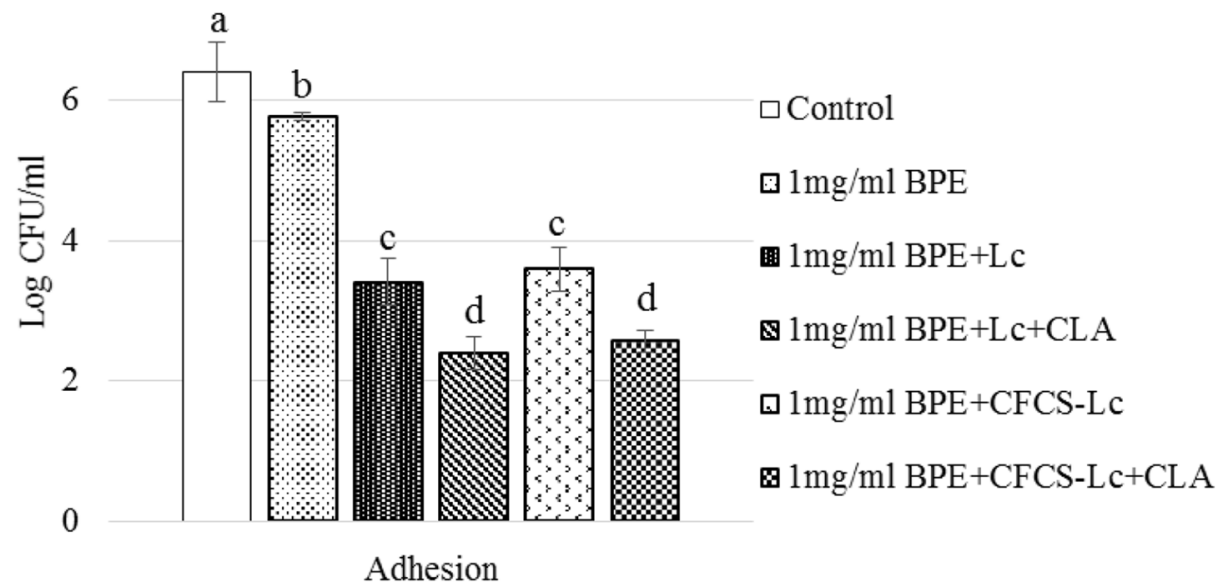

Fig. 2 Adhesion of EHEC to INT-407 cells with or without pre-treatments (A-C) with probiotics (LC or LC +CLA) and their metabolites in CFCSs. Error bars indicate standard deviation from 6 parallel trails. Bars with different letters (a through d) are significantly different when compared with control and among the treatments at $p<0.05$ 
Table 1 Physicochemical properties of EHEC treated with BPEs/CFCSs collected from overnight culture of Lc/Lc + CLA

\begin{tabular}{|c|c|c|c|}
\hline Treatment & Auto-aggregation (\%) & Hydrophobicity (\%) & Injured cell (\%) \\
\hline Control & $5.89 \pm 1.47^{*, a}$ & $13.1 \pm 2.16^{\mathrm{a}}$ & $16.52 \pm 5^{\mathrm{a}}$ \\
\hline $0.1 \mathrm{mg} / \mathrm{ml} \mathrm{GAE}$ & $5.38 \pm 1.61^{\mathrm{a}}$ & $9.87 \pm 2.52^{\mathrm{ab}}$ & $26.84 \pm 5.07^{\mathrm{ab}}$ \\
\hline $0.1 \mathrm{mg} / \mathrm{ml} \mathrm{GAE}+\mathrm{CFCS}-\mathrm{LC}$ & $4.65 \pm 2.7^{\mathrm{a}}$ & $8.28 \pm 2.49^{b c}$ & $41.4 \pm 5.57^{\mathrm{bc}}$ \\
\hline $0.1 \mathrm{mg} / \mathrm{ml} \mathrm{GAE}+\mathrm{CFCS}-\mathrm{Lc}+\mathrm{CLA}$ & $2.91 \pm 1.52^{\mathrm{ab}}$ & $4.57 \pm 2.06^{b c}$ & $50.35 \pm 3.93^{c}$ \\
\hline $0.5 \mathrm{mg} / \mathrm{ml} \mathrm{GAE}$ & $4.45 \pm 1.34^{\mathrm{a}}$ & $8.38 \pm 1.98^{b}$ & $36.33 \pm 6.06^{\mathrm{b}}$ \\
\hline $0.5 \mathrm{mg} / \mathrm{ml} \mathrm{GAE}+\mathrm{CFCS}-\mathrm{LC}$ & $3.41 \pm 1.56^{\mathrm{a}}$ & $6.85 \pm 1.77^{b c}$ & $45.9 \pm 4.77^{\mathrm{bc}}$ \\
\hline $0.5 \mathrm{mg} / \mathrm{ml} \mathrm{GAE}+\mathrm{CFCS}-\mathrm{Lc}+\mathrm{CLA}$ & $2.18 \pm 1.21^{b}$ & $3.5 \pm 1.2 \mathrm{~d}^{\mathrm{c}}$ & $53.2 \pm 7.01^{c}$ \\
\hline $1.0 \mathrm{mg} / \mathrm{ml} \mathrm{GAE}$ & $3.69 \pm 0.86^{\mathrm{a}}$ & $6.36 \pm 1.74^{b c}$ & $45.34 \pm 5.42^{b c}$ \\
\hline $1.0 \mathrm{mg} / \mathrm{ml} \mathrm{GAE}+$ CFCS-LC & $2.78 \pm 1.41^{b}$ & $4.8 \pm 1.54^{c}$ & $49.92 \pm 6.47^{b c}$ \\
\hline $1.0 \mathrm{mg} / \mathrm{ml} \mathrm{GAE}+\mathrm{CFCS}-\mathrm{Lc}+\mathrm{CLA}$ & $1.45 \pm 0.02^{b}$ & $2.89 \pm 1.14^{c}$ & $58.97 \pm 3.45^{c}$ \\
\hline
\end{tabular}

*Values indicate mean \pm standard deviation and means with different letters $(a-c)$ within the same column are different when compared with control and among the treatments at $\mathrm{p}<0.05$

satisfy the previous reports in which we observed that CLA overproducing strain, Lc + CLA and its metabolites containing CFCSs could alter the pathogenesis of several enteric bacterial pathogens including EHEC, Salmonella and Campylobacter jejuni [23, 24]. It has been also reported that CLA improved host gut health and immunity by protecting against inflammation and also play important role in metabolic pathways and in balancing gut microbial ecosystem [26, 27]. Further, researchers have reported that secondary plant metabolites containing bioactive phenolic extracts possess antimicrobial and anti-oxidant properties $[28,29]$. In our laboratory, we also found that phenolic extracts from blueberry and blackberry pomace could inhibit the growth and survival of various enteric bacterial pathogens including Salmonella and Campylobacter and altered the virulence properties of these pathogens and their interaction with host cells $[12,15,30]$. In our in vivo study, we also found that BPE can reduce the colonization of enteric bacterial pathogen Campylobacter in chicken gut on concentration dependent manners and a very trace amount $(0.1 \mathrm{GAE} \mathrm{mg} / \mathrm{ml})$ of BPEs also act as a growth promoter in chicken [31]. In this study, we found the combined effects CLA over-producing Lactobacillus strain with various concentration of BPEs can inhibit the growth and alter different pathogenic traits of EHEC at higher efficacy compared to BPEs at the same concentration alone.

In this current study, we also observed that CFCSs collected from either Lc or Lc + CLA could modify the growth and pathogenesis of EHEC and effect of CFCSs on EHEC growth reduction may not only depend on medium acidification, as growth of EHEC at a wide range of $\mathrm{pH}$ was previously observed [32]. As anti-pathogenic traits of phenolic compounds and Lc + CLA along with other metabolites in CFCSs showed an intensive effect on EHEC, it can be inferred that both metabolites produced by Lc or Lc + CLA and bioactive phenolic components of berry pomace could act synergistically, also found previously [33].

As attachment is considered to be important virulence properties, in this study we observed that adhesion efficacy of EHEC was reduced significantly in cultured mammalian intestinal epithelial cells, INT-407 in co-culture with Lc or Lc + CLA or treated by the CFCSs obtained from overnight culture of Lc or Lc + CLA in presence of BPEs. Higher concentrations of BPEs alone could reduce the adhesion efficacy significantly compared to growth media without any supplement. It has been reported before that similar carbohydrate-binding specific proteins are displayed on Lactobacillus spp. surface and may involve in decreasing the adhesiveness of enteric bacterial pathogens by pre-occupying the surface receptors on host cells [34]. Researchers have also reported that CFCSs, collected from various condition of Lactobacillus spp. also restricted the cells adhesion to host epithelial cells by different enteric bacterial pathogens $[4,35]$. To further investigate the attenuated bacterial virulence at gene expression level, we observed that the expression level of different virulence genes. The ler is the main transcriptional regulator for EHEC that modulates all effectors especially espA, espB, espD, eaeA and tir for attaching and effacing of the bacteria $[36,37]$ and were down regulated in the presence of the treatments of this study. This finding indicated that the down-regulation of the transcriptional regulator repressed the expression of effector genes for bacterial attachment, and therefore directly related to the reduction of EHEC-host cell interactions and other pathogenicity related traits.

Several groups of researchers reported positive relation among hydrophobicity, auto-aggregation and cell association activities [38-40]. In this study, combined treatments with CFCSs from Lc/Lc + CLA in presence of BPEs 

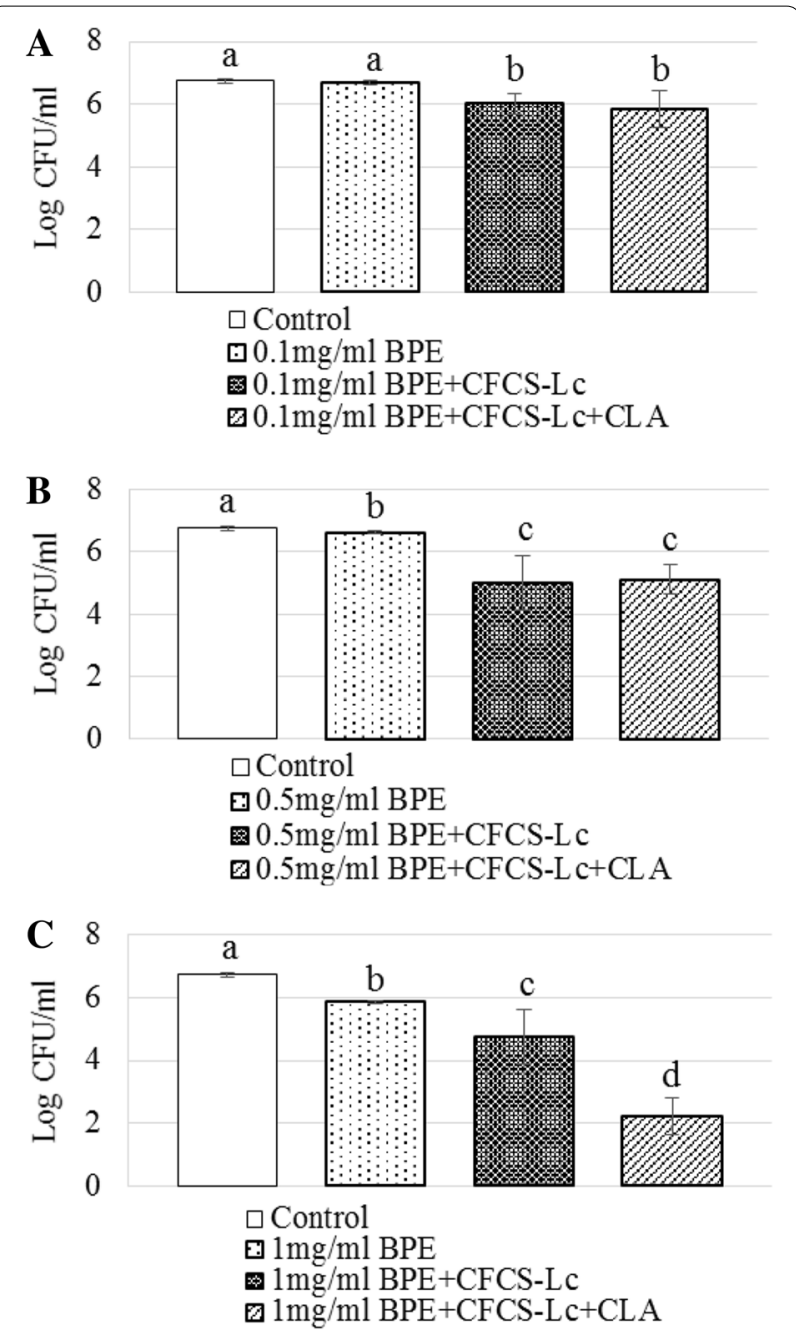

Fig. 3 Biofilm formation pattern of EHEC $(\mathbf{A}-\mathbf{C})$ treated with BPEs alone or CFCSs collected from LC or LC +CLA grown in the presence of BPEs. Error bars indicate standard deviation from 6 parallel trails. Different letters $(a-d)$ indicate the significant reduction in biofilm formation when compared with control and among the treatments at $p<0.05$

resulted in decreased hydrophobicity and auto-aggregation, which might impact on the reduction of adhesiveness in EHEC into INT-407 cells [12, 22, 41]. We also observed deferred ability of biofilm formation by EHEC with the combined treatments of CFCSs collected from either Lc or Lc + CLA in presence of different concentrations of BPEs. A positive association between bacterial auto-aggregation, cell surface hydrophobicity to biofilm formation ability has also been reported previously and our findings agreed with other study [42]. Injured but viable EHEC cell percentage was increased significantly by all the treatments and the effect intensified with the higher concentrations of BPEs or higher concentrations of bioactive metabolites, as higher concentration of BPEs were more efficient or CFCS from Lc + CLA was more effective compared to CFCS from Lc in presence of the same concentration of BPE. We hypothesized that the ratio of injured bacterial cells depends on the anti-pathogenic metabolites present in the treatments.

\section{Conclusion}

Probiotics specifically linoleic acid over-producing Lactobacillus strain, Lc + CLA, in the presence of BPEs exhibited rigorous effects on EHEC pathogenesis. Further, the growth medium supplemented with trace amount of BPEs stimulated the growth of probiotic strains [33], and also intensified the inhibitory effect of CFCSs collected from Lc + CLA on growth and survival of EHEC and altered the INT-407 cells-EHEC interactions. The promising roles of the combination of the genetically engineered probiotic strain, Lc + CLA and bioactive BPEs in controlling foodborne infection with EHEC, particularly growth inhibition, physicochemical properties alteration, disruption of EHEC-host cell interactions, and its virulence genes suppression indicated the possibility to make this synbiotic potential alternative to preventive and/ or therapeutics for EHEC infection in human. In future, the effectiveness of the synbiotic is needed to confirm in appropriate animal model.

\section{Materials and method}

\section{Bacterial strains and growth conditions}

In this study, enterohemorrhagic Escherichia coli EDL933 (EHEC) (ATCC 700927) was grown on LuriaBertani (LB) agar (EMD Chemicals Inc., USA) for $18 \mathrm{~h}$ at $37{ }^{\circ} \mathrm{C}$ under aerobic conditions (Thermo Fisher Scientific Inc., USA). Probiotic strains, Lactobacillus casei (Lc) (ATCC 334) and lineolate over-expressed bioactive $L$. casei (Lc + CLA) [23, 24] were grown on de Man Rogosa Sharpe (MRS) agar (EMD Chemicals Inc., USA) overnight at $37{ }^{\circ} \mathrm{C}$ under aerobic condition with $5 \% \mathrm{CO}_{2}$ (Thermo Fisher Scientific Inc., USA).

\section{Preparation of pomace phenolic extracts}

Commercial blackberry and blueberry pomaces was donated by Milne Fruit Products Inc., Prosser, WA, USA, and BPE was extracted following the protocol previously reported [13]. Spectrophotometric method was used to measure the concentration of BPE and expressed as GAE [43]. BPE was comprised of blackberry and blueberry pomace extracts at $1: 1 \mathrm{v} / \mathrm{v}$ ratio for this study. 


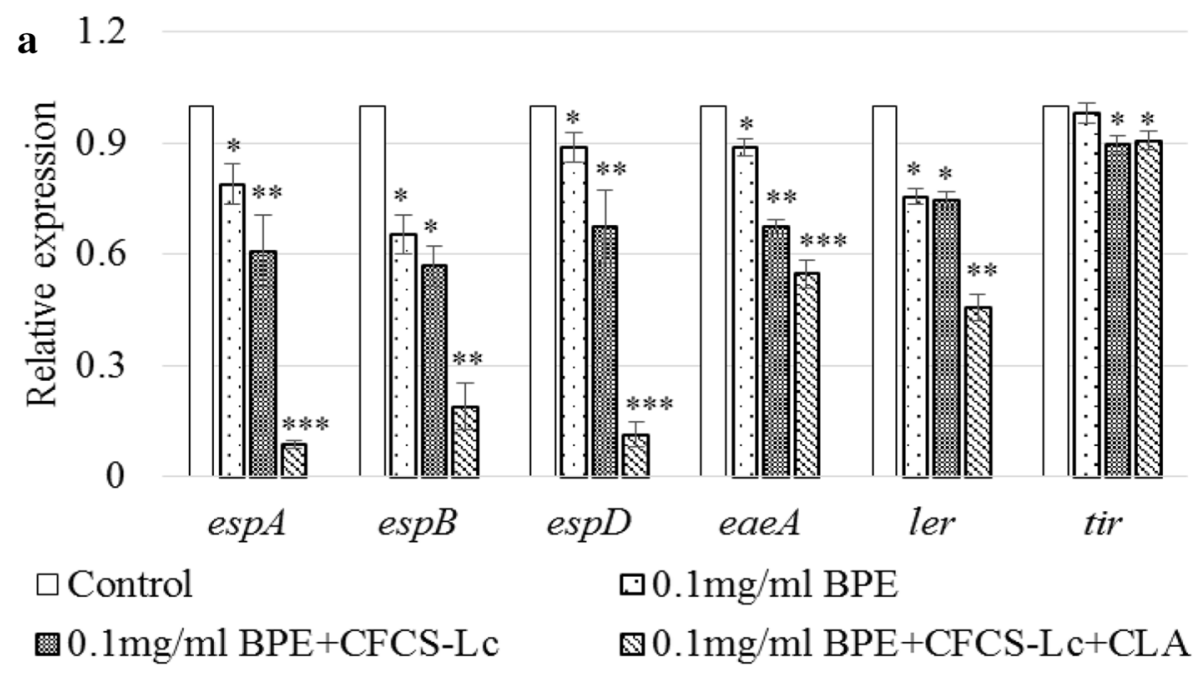

b 1.2

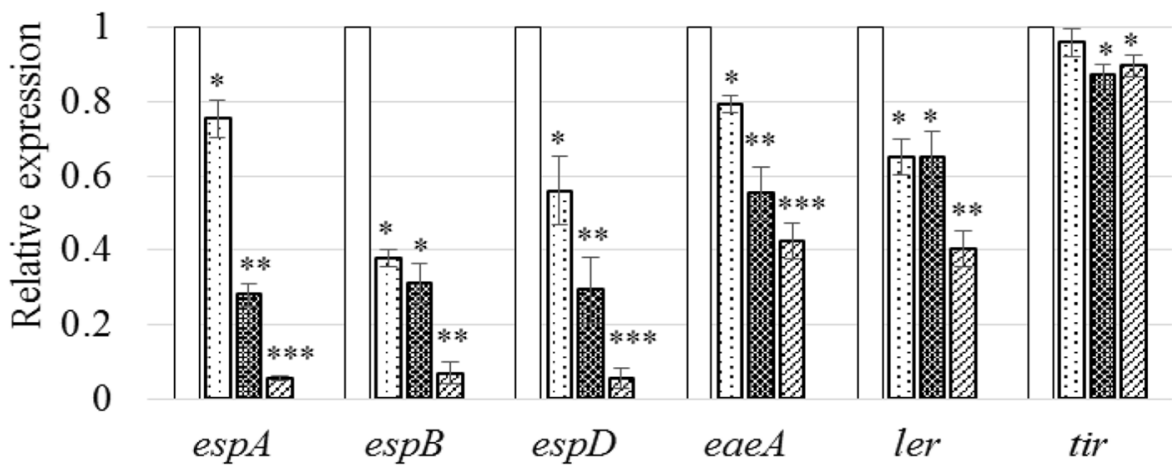

$\square$ Control

๑ $0.5 \mathrm{mg} / \mathrm{ml} \mathrm{BPE}$

$0.5 \mathrm{mg} / \mathrm{ml} \mathrm{BPE}+\mathrm{CFCS}-\mathrm{Lc}$

웅 $0.5 \mathrm{mg} / \mathrm{ml} \mathrm{BPE}+\mathrm{CFCS}-\mathrm{Lc}+\mathrm{CLA}$

c 1.2

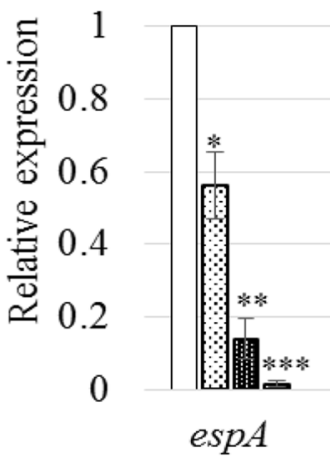

$\square$ Control

国 $1 \mathrm{mg} / \mathrm{ml} \mathrm{BPE}+\mathrm{CFCS}-\mathrm{Lc}$

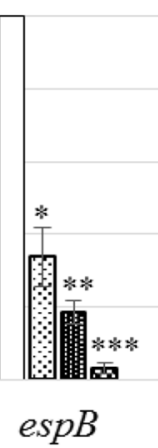

$\operatorname{esp} B$

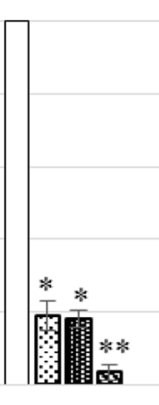

$\operatorname{espD}$

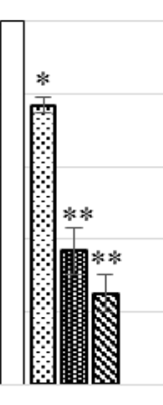

eaeA

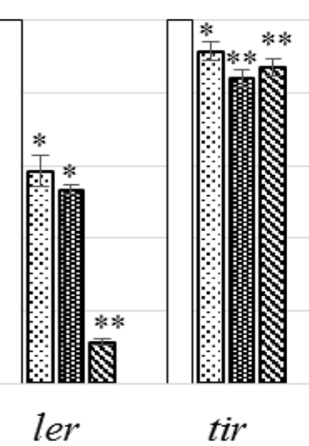

용 $1 \mathrm{mg} / \mathrm{ml} \mathrm{BPE}$

\$ $1 \mathrm{mg} / \mathrm{ml} \mathrm{BPE}+\mathrm{CFCS}-\mathrm{Lc}+\mathrm{CLA}$

Fig. 4 Relative expression of different virulence genes of EHEC (a-c) treated with BPEs alone or CFCSs collected from LC or LC+CLA grown in the presence of BPEs $(0.1 \mathrm{mg} / \mathrm{ml} \mathrm{GAE}$ or $0.5 \mathrm{mg} / \mathrm{ml} \mathrm{GAE}$ or $1.0 \mathrm{mg} / \mathrm{ml} \mathrm{GAE})$. Error bars indicate standard deviation from 6 parallel trails. Bars with different number of asterisks ${ }^{*}$ ) are significantly different at $p<0.05$ 


\section{Mammalian cell and culture conditions}

Human intestinal epithelial (INT-407) (ATCC CCL-6) cells were cultured at $37^{\circ} \mathrm{C}$, standard condition $\left(5 \% \mathrm{CO}_{2}\right)$ in Dulbecco's Modified Eagle Medium (DMEM) (Corning Cellgro, USA) supplemented with $10 \%$ heat-inactivated Fetal Bovine Serum (FBS) (Corning Cellgro, USA) and $50 \mu \mathrm{g} / \mathrm{ml}$ of gentamycin (Lonza, USA). For monolayer preparation, INT-407 cells were seeded in 24-well culture plate (Greiner Bio-one Inc., USA) at $2 \times 10^{5}$ cells $/ \mathrm{ml}$ and maintained following the standard protocol described as above to form $>90 \%$ confluence monolayer. Before use, the monolayers were washed with phosphate buffer saline (PBS) three times and immersed in antibiotic free DMEM supplemented with 5\% heat-inactivated FBS [24].

\section{Cell free culture supernatant}

Cell free culture supernatant (CFCS) of overnight liquid cultures of Lc, and Lc + CLA were collected following the method previously reported by our laboratory [21] and collected CFCSs were filtered and stored at $4{ }^{\circ} \mathrm{C}$.

\section{Growth inhibition assay}

Inhibition of EHEC growth was carried out in presence of different concentrations of BPEs $(0.1 \mathrm{mg} / \mathrm{ml}$ GAE or $0.5 \mathrm{mg} / \mathrm{ml} \mathrm{GAE}$ or $1.0 \mathrm{mg} / \mathrm{ml} \mathrm{GAE}$ ) and/or Lc or LC + CLA. All bacterial strains were grown on selective respective agar plates following the method described above. A volume of $400 \mu \mathrm{l}$ of Lc or Lc + CLA bacterial suspension containing approximately $10^{7} \mathrm{CFU} / \mathrm{ml}$ was mixed with equal volume of EHEC suspension containing approximately $10^{6} \mathrm{CFU} / \mathrm{ml}$ in $3.2 \mathrm{ml}$ of LB broth and incubated at $37{ }^{\circ} \mathrm{C}$ in presence of different concentrations $(0.1 \mathrm{mg} / \mathrm{ml} \mathrm{GAE}$ or $0.5 \mathrm{mg} / \mathrm{ml} \mathrm{GAE}$ or $1.0 \mathrm{mg} / \mathrm{ml} \mathrm{GAE})$ of BPE. Serial dilutions were performed in PBS, followed by plating on LB agar for EHEC at 0, 24, 48, and $72 \mathrm{~h}$ time points. For inhibition assay with CFCSs, instead of live Lc or Lc + CLA, $400 \mu \mathrm{l}$ of CFCS-LC (collected from Lc) or CFCS-Lc + CLA (collected from Lc + CLA) with/without BPEs were mixed with equal volume of EHEC suspension containing approximately $10^{6} \mathrm{CFU} / \mathrm{ml}$ in $3.2 \mathrm{ml}$ of $\mathrm{LB}$ broth and incubated at $37{ }^{\circ} \mathrm{C}$ and counted following the above mentioned plating methods at $0,24,48 \mathrm{~h}$ and $72 \mathrm{~h}$ time points.

\section{Cell adhesion assay}

Adhesion of EHEC to INT-407 cell was performed following the method described previously [21, 24]. Briefly, INT-407 cell monolayers were pre-treated with $100 \mu \mathrm{l}$ DMEM (control), different concentrations of BPEs $(0.1 \mathrm{mg} / \mathrm{ml} \mathrm{GAE}$ or $0.5 \mathrm{mg} / \mathrm{ml} \mathrm{GAE}$ or $1.0 \mathrm{mg} / \mathrm{ml} \mathrm{GAE})$ or with probiotics or their CFCS in presence of different concentrations of BPEs $(0.1 \mathrm{mg} / \mathrm{ml} \mathrm{GAE}$ or $0.5 \mathrm{mg} / \mathrm{ml}$ $\mathrm{GAE}$ or $1.0 \mathrm{mg} / \mathrm{ml} \mathrm{GAE}$ ) for $1 \mathrm{~h}$ (triplicates). After pretreatment, $100 \mu \mathrm{l}$ of EHEC, bacterial suspension with multiplicity of infection (MOI) of $10\left(2 \times 10^{6} \mathrm{CFU} / \mathrm{ml}\right)$ were inoculated into each well, followed by $2 \mathrm{~h}$ incubation, lysis by $0.1 \%$ Triton X-100 for $15 \mathrm{~min}$, serial dilutions and plating for quantification.

\section{Physiological properties of EHEC in the presence of probiotics or their CFCS and/or BPEs}

Changes of physicochemical properties including cell surface hydrophobicity, auto-aggregation and injured cell ratio of EHEC were evaluated following the methodologies previously described [16] with modifications in culture condition. In brief, EHEC was grown in LB broth or LB broth with BPEs $(0.1 \mathrm{mg} / \mathrm{ml} \mathrm{GAE}$ or $0.5 \mathrm{mg} / \mathrm{ml}$ GAE or $1.0 \mathrm{mg} / \mathrm{ml} \mathrm{GAE)} \mathrm{or} \mathrm{CFCSs} \mathrm{collected} \mathrm{from} \mathrm{Lc} \mathrm{or}$ $\mathrm{Lc}+\mathrm{CLA}$ in combination with BPEs at $37^{\circ} \mathrm{C}$ for $18 \mathrm{~h}$.

\section{EHEC biofilm formation}

The ability of EHEC to form biofilms on glass surfaces in the absence or presence of CFCSs and/or BPEs was performed following the method previously described [16]. Briefly, $100 \mu \mathrm{l}$ of EHEC, containing approximately $5 \times 10^{5} \mathrm{CFU} / \mathrm{ml}$, was inoculated in triplicate in wells of 6-well plates (Corning, USA) containing $22 \times 22 \mathrm{~mm}^{2}$ glass slides. Wells containing LB broth (control) or LB broth supplemented with different concentrations of BPEs $(0.1 \mathrm{mg} / \mathrm{ml} \mathrm{GAE}$ or $0.5 \mathrm{mg} / \mathrm{ml} \mathrm{GAE} \mathrm{or} 1.0 \mathrm{mg} / \mathrm{ml}$ GAE), or CFCSs with BPEs were incubated for 48 without shaking at $37{ }^{\circ} \mathrm{C}$. Then, the glass slides were rinsed with PBS for five times and bacterial cells were recovered using sterile cell scraper (VWR, USA) from the glass surface and enumerated.

\section{RNA extraction, cDNA synthesis and quantitative RT-PCR assay} EHEC was grown in the absence or presence of BPEs $(0.1 \mathrm{mg} / \mathrm{ml} \mathrm{GAE}$ or $0.5 \mathrm{mg} / \mathrm{ml} \mathrm{GAE}$ or $1.0 \mathrm{mg} / \mathrm{ml} \mathrm{GAE})$ or/and CFCSs collected from Lc or Lc + CLA and RNA was extracted according to the protocol of ZR Bacterial RNA MiniPrep kit (Zymo Research Corp., USA). The RNA quantification was carried out using NanoDrop spectrophotometer (Thermo Scientific Inc., USA) and cDNA synthesis was performed according to the protocol provided by Quanta Biosciences, USA. The customsynthesized oligonucleotide primers for $\operatorname{esp} A, \operatorname{esp} B$, espD, eaeA, ler, tir of EHEC were purchased from Eurofins MWG Operon, USA and methodology previously described [44] was followed to perform the qRT-PCR assay. 


\section{Statistical analysis}

Collected data were analyzed by the Statistical Analysis System software (SAS Institute Inc., USA). The one-way analysis of variance (ANOVA) for each single time point followed by Tukey's test was used to evaluate the various treatments and significant differences among control and treatments were determined based on significant level of 0.05 .

\begin{abstract}
Abbreviations
BPE: berry pomace (byproduct) phenolic extract; CFCS: cell-free cultural supernatant; CFU: colony forming unit; CLA: conjugated linoleic acid; DMEM: Dulbecco's Modified Eagle Medium; EHEC: enterohemorrhagic Escherichia coli; FBS: fetal bovine serum; GAE: gallic acid equivalent; HUS: hemolytic uremic syndrome; LA: linoleic acid; LB: Luria-Bertani; Lc: Lactobacillus casei; Lc + CLA: genetically engineered strain of Lactobacillus casei; LEE: locus of enterocyte effacement; Mcra: myosin cross-reactive antigen; MRS: de Man Rogosa Sharpe; PBS: phosphate buffer saline.
\end{abstract}

\section{Acknowledgements}

We would like to thank Milne Fruit Products Inc., Prosser, WA, USA for the blackberry and blueberry pomaces.

\section{Authors' contributions}

ZT designed the study, carried out the experiments, drafted the initial manuscript and revised the manuscript. MP carried out the experiments and reviewed the manuscript. CB, PP and $M C$ helped in carrying out the experiments. DB conceptualized and designed the study, reviewed and revised the manuscript. All authors read and approved the final manuscript.

\section{Funding}

Not applicable.

\section{Availability of data}

The raw data and/or analysis of the current study are available from the corresponding author on reasonable request.

\section{Ethics approval and consent to participate}

Not applicable.

\section{Consent for publication}

Not applicable.

\section{Competing interests}

The authors declare that they have no competing interests.

\section{Author details}

${ }^{1}$ Biological Sciences Program-Molecular and Cellular Biology, University of Maryland, College Park, MD, USA. ${ }^{2}$ Department of Animal and Avian Sciences, University of Maryland, 8127 Regents Drive, College Park, MD, USA.

${ }^{3}$ Center for Food Safety and Security Systems, University of Maryland, College Park, MD, USA.

Received: 15 April 2019 Accepted: 20 July 2019

Published online: 27 July 2019

\section{References}

1. Bielaszewska $M$, Schiller $R$, Lammers $L$, et al. Heteropathogenic virulence and phylogeny reveal phased pathogenic metamorphosis in Escherichia coli O2:H6. EMBO Mol Med. 2014;6(3):347-57.

2. Martina B, Evgeny Al, Wenlan Z, et al. Effects of antibiotics on shiga toxin 2 production and bacteriophage induction by epidemic Escherichia coli O104:H4 strain. Antimicrob Agents Chemother. 2012;56(6):3277-82.
3. Carone BR, Xu T, Murphy KC, et al. High incidence of multiple antibiotic resistant cells in cultures of in enterohemorrhagic Escherichia coli O157:H7. Mutat Res. 2013;759:1-8.

4. Campana R, Sara F, Eleonora C, et al. Antagonistic activity of Lactobacillus acidophilus ATCC 4356 on the growth and adhesion/invasion characteristics of human Campylobacter jejuni. Curr Microbiol. 2012;64(4):371-8.

5. Galdeano CM, Perdigón G. The probiotic bacterium Lactobacillus casei induces activation of the gut mucosal immune system through innate immunity. Clin Vaccine Immun. 2006;13(2):219-26.

6. Servin AL, Coconnier MH. Adhesion of probiotic strains to the intestinal mucosa and interaction with pathogens. Bailliere's Best Pract Res Clin Gastroenterol. 2003;17(5):741-54.

7. Medellin-Peña MJ, Wang H, Johnson R, et al. Probiotics affect virulencerelated gene expression in Escherichia coli O157:H7. Appl Environ Microbiol. 2007;73(13):4259-67.

8. Sperandio V, Li CC, Kaper JB. Quorum-sensing Escherichia coli regulator $A$ : a regulator of the LysR family involved in the regulation of the locus of enterocyte effacement pathogenicity island in enterohemorrhagic $E$. coli. Infect Immun. 2002;70(6):3085-93.

9. Feng $X, N g$ VK, Mikš-Krajnik M, et al. Effects of fish gelatin and tea polyphenol coating on the spoilage and degradation of myofibril in fish fillet during cold storage. Food Bioprocess Technol. 2017;10(1):89-102.

10. Muthaiyan A, Biswas D, Crandall PG, et al. Application of orange essential oil as an anti-staphylococcal agent in a dressing model. BMC Complement Altern Med. 2012. https://doi.org/10.1186/1472-6882-12-125.

11. Sudjana AN, D'Orazio C, Ryan V, et al. Antimicrobial activity of commercial Olea europaea (olive) leaf extract. Int J Antimicrob Agents. 2009;33(5):461-3.

12. Salaheen $\mathrm{S}$, Jaiswal $\mathrm{E}, \mathrm{J}$ oo J, et al. Bioactive extracts from berry byproducts on the pathogenicity of Salmonella Typhimurium. Int J Food Microbiol. 2016;237:128-35

13. Salaheen S, Almario JA, Biswas D. Inhibition of growth and alteration of host cell interactions of Pasteurella multocida with natural byproducts. Poult Sci. 2014;93(6):1375-82.

14. Salaheen $S$, White $B$, Bequette $B J$, et al. Peanut fractions boost the growth of Lactobacillus casei that alters the interactions between Campylobacter jejuni and host epithelial cells. Food Res Int. 2014;62:1141-6.

15. Salaheen S, Nguyen C, Mui C, et al. Bioactive berry juice byproducts as alternative and natural inhibitors for Salmonella gallinarum and Salmonella pullorum. J Appl Poult Res. 2015;24(2):186-97.

16. Yang $H$, Hewes $D$, Salaheen $S$, et al. Effects of blackberry juice on growth inhibition of foodborne pathogens and growth promotion of LactobacilIus. Food Control. 2014;37(1):15-20.

17. Callaway TR, Edrington TS, Anderson RC, et al. Gastrointestinal microbial ecology and the safety of our food supply as related to Salmonella. J Anim Sci. 2008;86(14):163-72.

18. Deriu E, Liu JZ, Pezeshki M, et al. Probiotic bacteria reduce Salmonella Typhimurium intestinal colonization by competing for iron. Cell Host Microbe. 2013;14(1):26-37.

19. Ohshima T, Kojima Y, Seneviratne CJ, et al. Therapeutic application of synbiotics, a fusion of probiotics and prebiotics, and biogenics as a new concept for oral Candida infections: a mini review. Front Microbiol. 2016. https://doi.org/10.3389/fmicb.2016.00010.

20. O'Shea EF, Cotter PD, Stanton C, et al. Production of bioactive substances by intestinal bacteria as a basis for explaining probiotic mechanisms: bacteriocins and conjugated linoleic acid. Int J Food Microbiol. 2012;152(3):189-205.

21. Peng $M$, Bitsko $E$, Biswas $D$. Functional properties of peanut fractions on the growth of probiotics and foodborne bacterial pathogens. J Food Sci. 2015;80(3):M635-41.

22. Peng M, Reichmann G, Biswas D. Lactobacillus casei and its byproducts alter the virulence factors of foodborne bacterial pathogens. J Funct Foods. 2015;15:418-28.

23. Peng M, Tabashsum Z, Patel P, et al. Linoleic acids overproducing Lactobacillus casei limits growth, survival, and virulence of Salmonella Typhimurium and enterohaemorrhagic Escherichia coli. Front Microbiol. 2018. https://doi.org/10.3389/fmicb.2018.02663.

24. Tabashsum Z, Peng M, Salaheen S, et al. Competitive elimination and virulence property alteration of Campylobacter jejuni by genetically engineered Lactobacillus casei. Food Control. 2018;85:283-91. 
25. Salaheen S, Kim SW, Haley BJ, et al. Alternative growth promoters modulate broiler gut microbiome and enhance body weight gain. Front Microbiol. 2017. https://doi.org/10.3389/fmicb.2017.02088.

26. Ross RP, Mills S, Hill C, et al. Specific metabolite production by gut microbiota as a basis for probiotic function. Int Dairy J. 2010;20(4):269-76.

27. Wahle KW, Heys SD, Rotondo D. Conjugated linoleic acids: are they beneficial or detrimental to health? Prog Lipid Res. 2004;43(6):553-87.

28. Nohynek LJ, Alakomi HL, Kähkönen MP, et al. Berry phenolics: antimicrobial properties and mechanisms of action against severe human pathogens. Nutr Cancer. 2006;54:18-32.

29. Puupponen-Pimiä R, Nohynek L, Alakomi HL, et al. Bioactive berry compounds - novel tools against human pathogens. Appl Microbiol Biotechnol. 2005;67(1):8-18.

30. Salaheen S, Nguyen C, Hewes D, et al. Cheap extraction of antibacterial compounds of berry pomace and their mode of action against the pathogen Campylobacter jejuni. Food Control. 2014;46:174-81.

31. Salaheen S, Tabashsum Z, Gaspard SA, et al. Reduced Campylobacter jejuni colonization in poultry gut with bioactive phenolics. Food Control. 2018;84:1-7.

32. Roberts TA, vanSchothorst M, Sharpe AN, BairdParker AC, Bryan FL Buchanan RL, Busta FF, Doyle MP, Farkas J, Grau FH, Hobbs BC. The international commission on microbiological specifications for foods (ICMSF): update. Food Control. 1996;7(2):99-101.

33. Tabashsum Z, Peng M, Kahan E, et al. Effect of conjugated linoleic acid overproducing Lactobacillus with berry pomace phenolic extracts on Campylobacter jejuni pathogenesis. Food Funct. 2019;10:296-303.

34. Neeser JR, Granato D, Rouvet M, et al. Lactobacillus johnsonii La1 shares carbohydrate-binding specificities with several enteropathogenic bacteria. Glycobiol. 2000;10(11):1193-9.

35. Bendali F, Hebraud M, Sadoun D. Anti-bacterial and anti-adherence activities of a probiotic strain of Lactobacillus paracasei against Listeria monocytogenes. IJAMBR. 2014;2:52-63.

36. DeVinney R, Stein M, Reinscheid D, et al. Enterohemorrhagic Escherichia coli O157:H7 produces Tir, which is translocated to the host cell membrane but is not tyrosine phosphorylated. Infect Immun. 1999;67(5):2389-98.
37. Franzin FM, Sircili MP. Locus of enterocyte effacement: a pathogenicity island involved in the virulence of enteropathogenic and enterohemorrhagic Escherichia coli subjected to a complex network of gene regulation. Biomed Res Int. 2015. https://doi.org/10.1155/2015/534738.

38. Lorite GS, Janissen R, Clerici JH, et al. Surface physicochemical properties at the micro and nano length scales: role on bacterial adhesion and Xylella fastidiosa biofilm development. PLOS ONE. 2013. https://doi. org/10.1371/journal.pone.0075247.

39. Oliveira FM, Dos Santos EM, Alves AC, et al. Digestion, absorption and tissue distribution of ovalbumin and palmitoyl-ovalbumin: impact on immune responses triggered by orally administered antigens. Scand J Immunol. 2007;65(2):139-47.

40. Saran S, Bisht MS, Singh K, et al. Comparing adhesion attributes of two isolates of Lactobacillus acidophilus for assessment of prebiotics, honey and inulin. Int J Sci Res Publ. 2012;2(1):2250-3153.

41. Golden NJ, Acheson DWK. Identification of motility and autoagglutination Campylobacter jejuni mutants by random transposon mutagenesis. Infect Immun. 2002;70(4):1761-71.

42. Wang H, Ding S, Dong Y, et al. Biofilm formation of Salmonella serotypes in simulated meat processing environments and its relationship to cell characteristics. J Food Protect. 2013;76(10):1784-9.

43. Singleton $\mathrm{VL}$, Orthofer $\mathrm{R}$, Lamuela-Raventos RM. Analisys of total phenols and other oxidation sobstrates and antioxidants by means of Folin Ciocalteau reagent. Methods Enzymol. 1999;299:52-78.

44. Peng M, Zhao X, Biswas D. Polyphenols and tri-terpenoids from Olea europaea $\mathrm{L}$. in alleviation of enteric pathogen infections through limiting bacterial virulence and attenuating inflammation. J Funct Foods. 2017;36:132-43.

\section{Publisher's Note}

Springer Nature remains neutral with regard to jurisdictional claims in published maps and institutional affiliations.
Ready to submit your research? Choose BMC and benefit from:

- fast, convenient online submission

- thorough peer review by experienced researchers in your field

- rapid publication on acceptance

- support for research data, including large and complex data types

- gold Open Access which fosters wider collaboration and increased citations

- maximum visibility for your research: over $100 \mathrm{M}$ website views per year

At BMC, research is always in progress.

Learn more biomedcentral.com/submissions 